\title{
CRYSTAL AND MOLECULAR STRUCTURE OF NOVEL SILVER-DIPHOSPHINE COMPLEXES
}

\author{
Francesco Caruso ${ }^{1}$ and Luigi M. Venanzi \\ ${ }^{1}$ Instituto di Strutturistica Chimica, CNR, Box 10, I - 00016 Monterotondo Stazione, Roma, Italy \\ 2 Eidgenossische Technische Hochschule, Universitätstraße 6, CH - 8092 Zürich, Switzerland
}

It has been shown that the bis-chelated complex $\mathrm{Au}(\mathrm{dppe}){ }_{2} \mathrm{Cl}$, dppe = diphenylphosphinoethane and derivatives are active against a series of tumor cell lines [1]. Later, closely related silver diphosphine complexes were shown to be cytotoxic against B melanoma cells in vitro and P $\mathbf{3 8 8}$ leukemia in mice [2]. Furthermore, Cu-diphosphine complexes are also biologically active [3]. The diphosphine ligands have been suggested as the cytotoxic species, since they are also active but less than some of their metal complexes [3]. Chelation seems to be an essential condition for biological activity in these complexes.

We have been studying the coordination properties of silver-phosphine complexes ([4] and references therein) and will review this chemistry, focusing on chelation conditions. We describe some Ag-complexes of the ligands 1,2-bis(diphenylphosphinomethyl)benzene and 1,3-bis(diphenylphosphinomethyl)benzene. The former ligand is able to give a new type of silver chelate species.

\section{References}

[1] C. K. Mirabelli, D. T. Hill, L. F. Faucette, F. L. McCabe, G. R. Girard, D. B. Bryan, B. M. Sutton, J. O'Leary Bartus, S. T. Crooke, and R. K. Johnson, J. Med. Chem. 1987, 30, 21812189.

[2] S. J. Berners-Price, R. K. Johnson, A. J. Giovenella, L. F. Faucette, C. K. Mirabelli, P. J. Sadler, J. Inorgan. Biochem. 1988, 33, 285-295.

[3] R. M. Snyder, C. K. Mirabelli, R. K. Johnson, C. Sung, L. F. Faucette, F. L. McCabe, J. P. Zimmerman, M. Whitman, J. C. Hempel, and S. T. Crooke, Cancer Res. 1986, 46, 50545060 .

[4] M. Camalli, F. Caruso, S. Chaloupka, and L. M. Venazi, Helv. Chim. Acta, 1988, 71, 703-711. 